\title{
WPŁYW ZBAWCZYCH MISTERIÓW JEZUSA CHRYSTUSA NA INTELIGENTNE ŻYCIE WE WSZECHŚWIECIE
}

DOI: http://dx.doi.org/10.12775/TiCz.2020.053

Streszczenie. Impulsem do podjęcia wskazanego w tytule zagadnienia stały się coraz powszechniejsze badania przestrzeni kosmicznej. Największe organizacje zajmujące się badaniem wszechświata jako takiego z coraz większą intensywnością prowadzą poszukiwania planet zdatnych do życia, a co za tym idzie również i życia mogącego rozwinąć się w innych ostępach przestrzeni. Im więcej odkrywamy egzoplanet podobnych do ziemi, obiegających swoje gwiazdy w tak zwanej ekosferze, tym częściej pytamy o ewentualnych mieszkańców tychże planet.

Temat ten w Kościele w żadnym razie nie jest niczym nowym, był bowiem z różnych skutkiem i w różnych okresach podejmowany, inni natomiast, jak np. św. Ojciec Pio, zdawkowo nawiązywali do wskazanego tematu. Logicznym następstwem prowadzonych badań jest więc pytania o wiarę tychże obcych nam istot. Czy są osobami? Czy popełniły grzech pierworodny? Czy ich zbawicielem jest Jezus ukrzyżowany i zmartwychwstały, czy też ich odkupienie dokonało się na innej drodze?

Na postawione pytania nie ma i póki co nie może być jasnej odpowiedzi, jednak to wcale nie oznacza, że nie powinniśmy szukać na nie odpowiedzi. Jednym z zadań każdego człowieka, niezależnie od prezentowanych poglądów, różnic etnicznych i kulturowych, jest szukanie prawdy. W to właśnie zadanie wpisuje się niniejszy artykuł.

Słowa kluczowe: życie pozaziemskie; osoba; zbawienie; wcielenie. 
Abstract. The Influence of the Salvific Mysteries of Jesus Christ on Intelligent Life in the Universe. The rapidly developing space exploration has become the impetus to take up the issue indicated in the title. The largest organizations that deal with the study of the universe as such with increasing intensity search for viable planets, and thus traces of life that can also develop in other hinterlands of space. The more we discover Earth-like exoplanets orbiting their stars in the so-called ecosphere, the more we ask about possible inhabitants of these planets.

This topic is by no means new in the Church, as it was undertaken with different results and at different times, while others, such as St. Padre Pio casually referred to the indicated topic. The logical consequence of the conducted research poses numerous questions about the faith of these aliens. Are they persons? Have they committed original sin? Is Jesus crucified and risen as their savior, or did their redemption takes place differently?

There is no clear answer to the questions posed, and so far there can be no clear resolution, but it does not mean that we should not look for answers to them. One of the tasks of every human being, regardless of the views, ethnic and cultural differences presented, is to seek the truth and this is what this article is about.

Keywords: extraterrestrial life; person; salvation; incarnation.

\section{1. (NIE)WYJĄTKOWOŚĆ ZIEMI}

Perspektywa istnienia światów, w których rozumne stworzenia uczyniły lepszy pożytek ze swej wolności niż ludzie, jest pocieszająca. Naukowcy odkryli już wiele planet podobnych do ziemi ${ }^{1}$. A skoro tak, to pojawiły się dywagacje o możliwości życia na innym globie i w ogóle we wszechświecie. Również życia rozumnego, a to prowadzi do rozważań także teologicznych. Wziąwszy pod uwagę, że tylko w naszej raczej mizernej galaktyce (mniej niż 100 tysięcy lat świetlnych) jest ok. 300 miliardów gwiazd, a co za tym idzie potencjalnych miejsc, tj. planet, do rozwoju życia jest jeszcze więcej - tylko nasze słońce trzyma bowiem w swoim uścisku aż 8 planet $^{2}$. Obok naszej galaktyki jest przeszło dwukrotnie większa Andromeda, która również jest mikrusem wobec chociażby galaktyki IC 1101 o średnicy 6 milionów lat świetlnych. Galaktyk jako takich we wszechświecie są również miliony. Potencjalnego miejsca jest więc pod dostatkiem³.

1 J. Shreeve, Halo, jest tam kto?, „National Geographic” 3, 2019, s. 36.

${ }^{2}$ C. Galfard, Wszechświat w twojej dłoni, Kraków 2017, s. 46.

3 Tamże, s. 56. 
Brytyjscy naukowcy, korzystając tylko i wyłącznie z danych i wiedzy, którą udało się zebrać o życiu na ziemi oraz o tym, co jest niezbędne, a co niepożądane $\mathrm{w}$ procesie kształtowania się inteligentnego życia, obliczyli, że w naszej galaktyce istnieć może nawet 30 zdolnych do komunikacji cywilizacji. Problem jednak jest w tym, że średnia odległość między nimi miałaby wynosić oszałamiające 17 lat świetlnych ${ }^{4}$. Takie szacunki nie opierają się na fantastyce naukowej, a jedynie na zdroworozsądkowym prawdopodobieństwie.

\section{CZłOWIEK JAKO OSOBA OTRZYMUJACA ZBAWIENIE}

W historii doświadczyliśmy już spotkań z „obcymi”, co do których również zastanawiano się, czy są ludźmi czy raczej zwierzętami. Mowa o spotkaniu Europejczyków z mieszkańcami obu Ameryk. Nieludzkie traktowanie można byłoby usprawiedliwić, gdyby nie miano do czynienia z ludzi. Taką narracje przyjęli koloniści uciemiężający i ograbiający Indian. Dlatego też na ten temat wypowiedział się Paweł III w breve Pastorale Officium, w którym uznał Indian za ludzi świadomych siebie, stworzonych na obraz Boży ${ }^{5}$. Papież w powyższym tekście stanął w obronie prawa do swobodnego przyjęcia wiary oraz do zbawienia. Poziom cywilizacyjny pomiędzy Europejczykami a Indianami był na tyle znaczący, że musiały pojawiać się pytania dotyczące ich godności. Już w XVI wieku człowiek rozumiał, że zbawcze misteria naszego Pana, swoim zasięgiem obejmują również tereny zupełnie nieznane, dopiero co odkryte. Człowiek został podniesiony do godności osoby wolnej, która jest w stanie nad sobą panować w odróżnieniu do reszty stworzenia. Nie jest niczyim niewolnikiem, a jego zadaniem jest oddawanie należnej czci Bogu oraz strzeżenie stworzonego świata przez rozumne nim zarządzanie ${ }^{6}$. Takim

4 T. Mileszko, W naszej galaktyce jest ponad 30 inteligentnych, kosmicznych cywilizacji, twierdzq brytyjscy naukowcy, https://www.komputerswiat.pl/aktualnosci/ nauka-i-technika/brytyjscy-naukowcy-w-naszej-galaktyce-jest-36-cywilizacji/v559d80 (05.10.2020).

5 I. Bokwa (red.), Breviarium Fidei, Poznań 2007, pkt. 305.

${ }^{6}$ G.L. Müller, Dogmatyka katolicka, Kraków 2015, s. 145. 
historycznym człowiekiem był również Jezus Chrystus ${ }^{7}$, który umarł na krzyżu za nasze grzechy ${ }^{8}$.

Bliskość Boga i człowieka po zmartwychwstaniu ujmowana jest w kategoriach osobowych, nie podlega już ograniczeniom przestrzenno-czasowym. Zmartwychwstały w tej rzeczywistości duchowej wciąż pozostaje tym samym, który cierpiał na krzyżu, ten Jezus, który umarł za nas na krzyżu, żyje teraz u Ojca9 ${ }^{9}$. Nie ogranicza Go ocean, kontynent lub przestrzeń kosmiczna - nie podlega też ograniczeniom czasu, ponieważ jak podaje autor listu do Hebrajczyków: „zawsze żyje, aby się wstawiać za nami”" ${ }^{\prime}$. Arcybiskup Życiński uważa, że śmierć Jezusa była zbawienna dla całego stworzenia, a więc również tego hipotetycznego, znajdującego się na innych planetach. Istotne jest jednak to, czy w historii takich istot pojawił się dramat grzechu pierworodnego, z którego wynikałaby potrzeba odkupienia ${ }^{11}$.

Godność człowieka czy samo miano „osoby” nie przynależy tylko do istot o wyprostowanej sylwetce, $\mathrm{z}$ dość dużym mózgiem (w stosunku do reszty ciała) i z przeciwstawnym kciukiem. Oprzeć możemy się tu na definicji sformułowanej przez Boecjusza, filozofa i teologa, który Osobę rozumie jako istotę rozumną, będącą podmiotem praw. Takiej istocie rozumnej, świadomej siebie i swoich praw przysługuje więc godność Osoby $^{12}$. Jednak wpływ misteriów zbawczych na takie osoby - jak się przekonamy jest różnie rozumiany.

\section{POWODY MARGINALIZACJI ŻYCIA POZAZIEMSKIEGO W TEOLOGII ORAZ NASTĘPSTWA POJAWIENIA SIĘ TEGOŻ TEMATU}

Nieliczni współcześni teologowie przejawiają zainteresowanie kwestią istnienia życia pozaziemskiego. Powodem mogą być dwa czynniki:

\footnotetext{
Tamże, s. 301.

81 Kor 15,3 .

9 G.L. Müller, dz. cyt., s. 326.

10 Hbr 7,25.

11 T. Rowiński, Aniołowie i kosmici, Kraków 2011, s. 39.

12 Tamże, s. 27.
} 
a) ludzkie skupienie na sobie - model geocentryczny przetrwał w naszym myśleniu jako skutek naszego zapatrzenia się w samych siebie, a rozwód teologii i nauki od czasów Darwina usunął kwestie życia pozaziemskiego z pola widzenia większości teologów;

b) niemal zupełny brak w Biblii, w tradycji oraz w gronie wiodących teologów rozsądnej refleksji teologicznej nad tą sprawą, co rodzi konieczność wykonania pionierskiej pracy budowy teologii życia pozaziemskiego ${ }^{13}$.

W szczególności należałoby rozważyć implikacje dla dzieła odkupienia, dokonywanego przez Chrystusa. Niektórzy teolodzy zaczynają stawiać pytania, których wcześniej nikt nie odważył się postawić:

a) Czy pojawi się konieczność sformułowania nowej dogmatyki i zwołania soboru, który pogodzi z biblijną koncepcją stworzenia istnienie wyższych o nas inteligencji?

b) Czy Jezus Chrystus umierał też na innych planetach, by zbawiać istoty pozaziemskie?

c) Czy to my będziemy ich nawracać czy one nas?

d) Co tamte cywilizacje wiedzą o Bogu?

Pytań jest wiele i nie zawsze można znaleźć na nie satysfakcjonujące odpowiedzi ${ }^{14}$.

\section{STANOWISKO KOŚCIOŁA W KWESTII ŻYCIA POZAZIEMSKIEGO}

Już Mikołaj z Kuz, kardynał, jeden z geniuszy średniowiecza, przekonywał, że „na innych gwiazdach są mieszkańcy innego rodzaju niż ci, którzy zamieszkują Ziemię". Na razie nie mamy jednak na to żadnej pewności, co najwyżej zdroworozsądkowe przewidywania. Podobnie w późniejszym czasie pisał inny duchowny, Giordano Bruno ${ }^{15}$. W 1879 roku o. Angelo Secchi stwierdził, że skoro istnieją istoty niższe od nas, to

${ }_{13}$ Teologia i nauka wobec cywilizacji pozaziemskich, https://portal.tezeusz.pl/blog/ teologia-i-nauka-wobec-cywilizacji-pozaziemskich/ (03.06.2020).

14 T.D. Wabll (red.), Życie we wszechświecie, Warszawa 2007, s. 10.

15 C. Galfard, dz. cyt., s. 52. 
$\mathrm{w}$ innych warunkach mogą istnieć istoty mądrzejsze od nas ${ }^{16}$. Nawet św. Ojciec Pio stwierdził w rozmowie ze swoją duchową córką: „Bóg z całą pewnością nie ograniczył swej chwały do tej małej planety” ${ }^{17}$.

Jezuita Domenico Grasso zauważył, że perspektywa istnienia światów, w których rozumne stworzenia uczyniły lepszy pożytek ze swej wolności niż ludzie, jest w gruncie rzeczy pocieszająca. Istnieje jednak wizja, że inne istoty również mogły zgrzeszyć, także mogą zmagać się ze skutkami grzechu pierworodnego, a jak wygląda to u nas doskonale widzimy i wcale nie jest to zbyt radosna wizja ${ }^{18}$.

Pionierami na polu teologii odnoszącej się nie tylko do ziemi i człowieka, lecz także do życia pozaziemskiego, tak zwanej egzoteologii, są min. Steven Dick - główny historyk NASA, George Coyne SJ z obserwatorium watykańskiego, Sjoered Bonting - teolog i biochemik, a także John Haught ${ }^{19}$.

Badania prowadzone przez astrobiologów spotykają się z zainteresowaniem Kościoła katolickiego. Może o tym świadczyć min. zorganizowanie w 2009 roku przez Papieską Akademię Nauk i Obserwatorium Watykańskie konferencji naukowej, poświęconej zagadnieniu poszukiwania życia pozaziemskiego. Ojciec Jose Funes SJ wyjaśnił, dlaczego Watykan zwrócił uwagę na ten temat, tłumaczy:

Chociaż astrobiologia jest nową dziedziną i nadal rozwijającym się tematem, pytania o początki życia i tego, czy istnieje życie we wszechświecie są bardzo interesujące i zasługują na poważne traktowanie. Pytania te powodują wiele implikacji filozoficznych i teologicznych ${ }^{20}$.

W swoim oświadczeniu przed Papieską Akademią Naukowców 27 października 2014 roku Franciszek poparł ideę, że życie we wszechświecie rozwijało się w sposób, który zgadza się z planem Stwórcy. Fran-

${ }^{16}$ Teologia i nauka wobec cywilizacji pozaziemskich, https://portal.tezeusz.pl/blog/ teologia-i-nauka-wobec-cywilizacji-pozaziemskich/ (05.10.2020).

17 C. Morcaldi, Moje życie w bliskości Ojca Pio, Kraków 2015, s. 89.

${ }^{18}$ D. Kowalczyk, Ewangelizowanie kosmitów?, „Gość Niedzielny” 13, 2017.

19 T.D. Wabll (red.), dz. cyt., s. 9.

${ }_{20}$ R. Butt, Vatican ponders extraterrestrials, https://www.theguardian.com/ world/2009/nov/11/vatican-extra-terrestrials-catholic (04.06.2019). 
ciszek oficjalnie wycofał się z pomysłu „Boga Stwórcy” jako magika lub wszechpotężnego artysty tworzącego wszechświat w ciągu sześciu dni i poszedł w kierunku bardziej naukowym, mówiącym że Bóg działa w tajemniczy sposób, za kulisami, planuje rozwój życia na Ziemi i w przestrzeni. Przemowa Papieża ukazuje, że życie pozaziemskie rozwinęło się w sposób, który zgadza się z Bożym planem, niezależnie od tego, jaki ów plan jest. Papież nalegał, aby wspierać bardziej zauważalny, bardziej przyjazny pogląd, że „Bóg Stwórca” działa tajemniczo poprzez stworzenie:

Stwórca jest $\mathrm{z}$ nami i jest również obecny $\mathrm{w}$ przyrodzie [...] naukowcy powinni być przekonani, że natura kryje w sobie mechanizm inteligencji i wolności, aby odkryć i uświadomić sobie to, że osiągnięcie rozwoju jako takiego jest częścią planu Stwórcy. On stworzył wszelkie istoty i pozwala im się rozwijać przez prawo wewnętrzne, które dał wszystkim dlatego, że są w stanie rozwijać się i wzrastać do pełnego rozwoju ich istoty. Wszechświat zapewnił także autonomię, która jest prawdziwa dla każdej rzeczywistości ${ }^{21}$.

Przemowa papieska robi również miejsce na ideę, że inteligentne życie może rozwijać się $\mathrm{w}$ wielu różnych światach i takie życie może osiągnąć „integralność istoty” i „autonomię”, co sprawia, że jest ważną częścią „planu Stwórcy”"22.

Ojciec Funes w wywiadzie dla dziennika „L'Osservatore Romano” podkreślił, że dopuszczalne jest stwierdzenie mówiące o istnieniu innych światów i innego życia, także bardziej rozwiniętego od naszego, bez kwestionowania wiary w stworzenie, wcielenie i zbawienie. Jezuita zauważył, że chociaż wielu astronomów deklaruje się jako ateiści, nie należy uważać, że astronomia sprzyja „ateistycznej wizji świata”. Nie jest powiedziane, że takie inteligentne istoty miałyby potrzebować zbawienia, bowiem mogłyby pozostać w pełnej przyjaźni ze swoim i naszym Stwórcą. Jeśli jednak okazałyby się grzeszne, to z pewnością, mogłyby mieć możliwość cieszenia się z miłosierdzia Boga tak jak my ${ }^{23}$.

${ }^{21}$ Pope Francis, Plenary Session on Evolving Concepts of Nature 24-28 October 2014, Vatican City http://www.pas.va/content/accademia/en/magisterium/francis/27october2014.html (06.10.2020).

22 Tamże.

${ }^{23} \mathrm{https} / /$ www.wprost.pl/swiat/129707/Watykan-mozna-wierzyc-w-istoty-pozaziemskie.html (06.10.2020). 
Czy są teologiczne podstawy przemawiające za możliwością istnienia życia pozaziemskiego? Teologia mówi o stwórczej płodności Boga-Stwórcy. Uczy ona o wszechmocy Boga, który niczym nieskrępowany daje początek czemuś, czego jeszcze nie ma, Jest wszechmogący, dlatego czyni, co chce, kiedy chce i gdzie chce. Bóg może zatem powoływać do istnienia. Mógłby więc stworzyć życie rozumne również gdzie indziej. Niemniej są to tylko przypuszczenia, choć niepozbawione racjonalnych podstaw $^{24}$.

\section{MODELE DOTYCZĄCE WCIELENIA I ODKUPIENIA NA INNYCH PLANETACH}

Ksiądz prof. George Coyne SJ, astrofizyk, stwierdził, że nie wiemy nic na temat tego, czy Bóg miał z istotami pozaziemskimi cokolwiek do czynienia. Nie mamy więc pojęcia, jakie mogłyby być tego konsekwencje dla naszej własnej wiary w Boga. Bo Bóg przemówił do nas - tylko to wiemy na pewno. Wszystko, co wiemy o Bogu, bierze się z tego, jak nam się objawił w Piśmie i przez naukę Kościoła. Nie sposób więc stwierdzić, jak relacje Boga z inną cywilizacją miałyby się przekładać na Jego relację z nami. Teilhard de Chardin twierdził, że Chrystus jest centrum całego stworzenia i przez fakt, że Bóg posłał do nas swojego jedynego Syna, zostało zbawione całe stworzenie. Dlatego Ojciec Coyne stwierdza, że zbawienie jest uniwersalne. Przyjmuje to za istotne postawienie sprawy, uważa to za dobry przykład uniwersalnej miłości Boga. Przestrzega jednak, że miłość Boga jest wolna, posłanie do nas swojego Syna, żeby nas zbawił, było Jego wolnym wyborem. Aktem wolności Boga, a nie Jego obowiązkiem. Pytanie, czy ów akt dotyczyłby tylko nas, czy całego Wszechświata - to już pójście krok dalej. Odpowiedź jest prawdopodobnie pozytywna, bo bardzo trudno byłoby nam zrozumieć miłość Boga, jeśli by się miało okazać, że jest wybiórcza ${ }^{25}$.

Jan Paweł II w encyklice Dominum et Vivificantem uczył, że Wcielenie ma także swój sens kosmiczny i kosmiczny wymiar. Pierworodny

${ }^{24}$ T.D. Wabll (red.), dz. cyt., s. 9.

${ }_{25}$ M. Kuźmiński (red.), Inne dzieci Boga, https://www.tygodnikpowszechny.pl/ inne-dzieci-boga-30199 (05.10.2020). 
wszelkiego stworzenia, wcielając się w konkretne człowieczeństwo Chrystusa, jednoczy się w pewien sposób z całą rzeczywistością człowieka, który jest także ciałem - a w niej z wszelkim ciałem, z całym stworzeniem. Papież przypomniał tym samym, że Wcielenie Chrystusa, jedna z centralnych tajemnic chrześcijaństwa, odnosi się nie tylko do samego człowieka, lecz swoim bogactwem obejmuje całe stworzenie, wręcz cały kosmos, również ewentualne stworzenia żyjące we wszechświecie, a przez nas jeszcze niepoznane ${ }^{26}$.

Teologia chrześcijańska, jak stwierdza ojciec Kijas, uczy, że stworzenie na obraz Boży nie odnosi się do fizycznej formy, ale mówi o duchowej naturze. Ta uwaga wskazuje, że o wielkości człowieka, czy innego stworzenia podobnego do niego, nie decyduje bynajmniej jego fizyczny kształt. W kontekście zbawienia również ich kolor skóry, długość ramion czy objętość czaszki nie będzie istotny, tak samo zresztą jak w przypadku ludzi. Najważniejsze znaczenie będzie miało ich życie duchowe, ich wrażliwość i otwartość na to, co się dzieje w nich samych, i wokół, na świat, który ich otacza, a w szczególności na bliźnich z którymi są w kontakcie ${ }^{27}$.

Czy zbawienie istot pozaziemskich wymagałoby powtórzenia wcielenia, śmierci i zmartwychwstania Chrystusa? Na to pytanie na łamach portalu Tezeusz odpowiedzi udziela Sjoerd L. Boting:

Van Vorilong stwierdził, że nie byłoby „właściwe”, gdyby Chrystus musiał udawać się do innego świata, by tam ponownie umrzeć. Był to raczej wyraz uczucia niż racjonalny pogląd teologiczny. E.L. Mascall rozważał tę kwestię w sposób bardziej teologiczny. Najpierw odrzucił skrajny pogląd kenotyczny, że poprzez wcielenie Chrystus ograniczył swoją boskość do ludzkiej miary, gdyż wtedy wcielenie nie mogłoby nastąpić na dwóch planetach jednocześnie. Odrzucił też koncepcję drugiego miejsca wcielenia już po wniebowstąpieniu Chrystusa. Stwierdził natomiast, że ortodoksyjny pogląd nie uznaje wcielenia za przemianę Bóstwa w ludzkie ciało, lecz podniesienie człowieczeństwa do boskiego poziomu. Inna skończona natura ewentualnych mieszkańców dalekich planet może więc z powodzeniem doznać takiego podniesienia. Odpowiedź na pytanie o wielokrotne wcielenia opiera się na innym rozumowaniu, ale również prowadzi do wniosku o niepowtarzalności Chrystusa. W ciągu wieków

${ }^{26}$ Jan Paweł II, Dominum et Vivificantem, Rzym 1986, pkt. 50n.

27 T. Rowiński, dz. cyt., s. 19-20. 
ludowe wierzenia chrześcijańskie zawęziły znaczenie wcielenia do roli samego tylko wstępu do zbawienia nas, ludzi. Za Pawłem ${ }^{28}$ i Janem ${ }^{29}$ oraz na podstawie naszej wiedzy o ewolucji kosmicznej i biologicznej można rozpoznać w Jezusie Chrystusa wręcz kosmicznego zbawiciela. Wcielenie, śmierć i zmartwychwstanie Jezusa Chrystusa w Palestynie przed dwoma tysiącami lat ma znaczenie kosmiczne i trwałe obowiązywanie ${ }^{30}$.

Przeciwna teoria zdaje się więc twierdzić, że nie ma potrzeby podejmowania przez Syna Bożego wielokrotnych wcieleńn ${ }^{31}$.

Obok wielokrotnego wcielenia występuje również inna propozycja ewentualnego objawienia, którą zaproponował francuski teolog Yves Congar. W przeszłości wyraził opinię, że na innych planetach niekoniecznie musiało odbywać się wcielenie Chrystusa. Zamiast tego to Trzecia Osoba Trójcy Świętej miałaby wcielić się w historię konkretnych, rozumnych istot pełniej i wyraziściej niż wydarzyło się to u nas. Na tej podstawie cytowany już wcześniej arcybiskup Józef Życiński stwierdził, że uzasadnione jest mówienie o spotkania z „braćmi w człowieczeństwie”32.

\section{ZAKOŃCZENIE I PODSUMOWANIE}

Kwestie wielokrotnego grzechu pierworodnego, wcielenia cierpienia i odkupienia istot podobnych nam co do natury istot zamieszkujących nieznane światy pozostaje nierozwiązana bowiem wciąż nie pozostaje w pełni podjęta. Czy jej podjęcie jest w ogóle konieczne? Może się okazać, że nigdy nie spotkamy żadnych przedstawicieli innych cywilizacji, ale może być też zupełnie odwrotnie. Co więc powinni robić ludzie wierzący? Tylko i wyłącznie szukać prawdy. Zainteresowanie kwestią istnienia życia pozaziemskiego jest dziś coraz głośniejszym zagadnieniem. Na przestrzeni ostatnich lat doszło nieomal do przewrotu w sposobie zadawania wspomnianego pytania. Ludzkość nie pyta już „czy” ale „gdzie” istnieje życie

282 Kor 5, 19

${ }^{29} \mathrm{~J} \mathrm{3}, 17$

${ }^{30}$ Teologia i nauka wobec cywilizacji pozaziemskich, https://portal.tezeusz.pl/blog/ /teologia-i-nauka-wobec-cywilizacji-pozaziemskich/ (05.10.2020).

31 T.D. Wabll (red.), dz. cyt., s. 202-203.

32 T. Rowiński, dz. cyt., s. 45-46. 
we wszechświecie. Wydaje się bardzo mało prawdopodobne, żebyśmy byli sami w tym gigantycznym wszechświecie. Carl Sagan stwierdził, że jeśli istniejemy tylko my, „to byłoby to okropne marnotrawstwo przestrzeni”" Uzasadnione staję się więc pytanie o religijny aspekt takich istot. W Papieskiej Akademii Nauk w 1996 r. Jan Paweł II powiedział: „prawda nie może zaprzeczać prawdzie", twierdząc, że Kościół katolicki nie ma się czego obawiać z postępu naukowego i jego wyzwań ${ }^{34}$. Dlatego niezależnie od tego, jaką wersję pytania przyjmiemy - „czy” lub „gdzie” istnieje życie pozaziemskie, Chrystus jest jedynym zbawicielem wszystkiego i wszyst$\mathrm{kich}^{35}$. Jest Prawdą, dlatego możemy być spokojni, bo prawda, nawet jeśli byłaby trudna, nie zdoła zaprzeczyć prawdzie, a w wielkiej kosmicznej przestrzeni zawsze będzie miejsce dla chrześcijan.

\section{BIBLIOGRAFIA}

[b.a.], Watykan: można wierzyć w istoty pozaziemskie, https://www.wprost.pl/swiat/129707/ Watykan-mozna-wierzyc-w-istoty-pozaziemskie.html (06.10.2020).

Bokwa I. (red.), Breviarium Fidei, Poznań 2007.

Butt R., Vatican ponders extraterrestrials, https://www.theguardian.com/world/2009/ nov/11/vatican-extra-terrestrials-catholic (06.10.2019).

Galfard C., Wszechświat w twojej dłoni, Kraków 2017.

Giangrave C., Could Catholicism handle the discovery of extraterrestrial life?, https://cruxnow.com/global-church/2017/02/catholicism-handle-discovery-extraterrestriallife/ (06.10.2020).

Jan Paweł II, Dominum et Vivificantem, Rzym 1986.

Kowalczyk D., Ewangelizowanie kosmitów?, „Gość Niedzielny” 13, 2017.

Kuźmiński M. (red.), Inne dzieci Boga, https://www.tygodnikpowszechny.pl/inne-dzieci-boga-30199 (05.10.2020).

Mileszko T., W naszej galaktyce jest ponad 30 inteligentnych, kosmicznych cywilizacji, twierdza brytyjscy naukowcy, https://www.komputerswiat.pl/aktualnosci/nauka-i-technika/brytyjscy-naukowcy-w-naszej-galaktyce-jest-36-cywilizacji/v559d80 (05.10.2020).

${ }^{33}$ C. Galfard, dz. cyt., s. 52.

${ }^{34}$ C. Giangrave, Could Catholicism handle the discovery of extraterrestrial life?, https://cruxnow.com/global-church/2017/02/catholicism-handle-discoveryextraterrestrial-life/ (06.10.2020).

351 Kor 8,6 . 
Morcaldi C., Moje życie w bliskości Ojca Pio, Kraków 2015.

Müller G.L., Dogmatyka Katolicka, Kraków 2015.

Pismo Święte Starego i Nowego Testamentu, Edycja Świętego Pawła, Częstochowa 2012.

Pope Francis, Plenary Session on Evolving Concepts of Nature 24-28 October 2014, Vatican City, http://www.pas.va/content/accademia/en/magisterium/francis/27october2014.html (06.10.2020).

Rowiński T., Aniołowie i kosmici, Kraków 2011.

Shreeve J., Halo, jest tam kto?, „National Geographic” 3, 2019.

Teologia i nauka wobec cywilizacji pozaziemskich, https://portal.tezeusz.pl/blog/teologia-i-nauka-wobec-cywilizacji-pozaziemskich/ (05.10.2020).

Wabll T.D. (red.), Życie we wszechświecie, Warszawa 2007. 